\title{
Growth Comparison of Israeli Carp (Cyprinus carpio) to Different Breeding Combination
}

\author{
Ju-ae Hwang, In Bon Goo, Jung Eun Kim, Myung Hun Kim, Do Hee Kim,

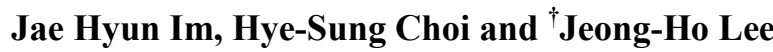 \\ Inland Aquaculture Research Center, National Institute of Fisheries Science (NIFS), Changwon 51688, Korea
}

\begin{abstract}
The purpose of this study was to investigate the improvement of growth in Israeli carp (Cyprinus carpio), and the cross experiment was carried out with two strains of Israeli carp. Four combinations of Israeli carp from Jeonbuk fisheries

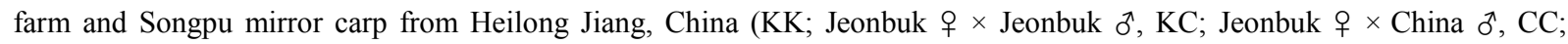
China $+9 \times$ China $\sigma^{\star}$ and CK; China $+\times$ Jeonbuk $\delta^{\Uparrow}$ ) were developed and reared. Body length, body weight and condition factor were determined at 20, 40, 60 and 170 days post-hatch (DPH). The results showed that there were differences in growth rate of the four groups. Body length of four groups were $\mathrm{CK}>\mathrm{CC}>\mathrm{KC}>\mathrm{KK}$ and body weight were $\mathrm{CC}>\mathrm{CK}>\mathrm{KC}>\mathrm{KK}$ at $170 \mathrm{DPH}$. The growth perfomance of four groups were statistically significant difference $(P<0.05)$. During the rearing, $\mathrm{CC}$ group had longer length and higher weight at $170 \mathrm{DPH}$ compared to other three groups and also condition factor was highest in the CC group, but there was no significant difference in a survival rate. These results indicated that the growth performance mainly depended upon brooder combination but survival rate could not significantly affect brooder.
\end{abstract}

Key words : Israeli carp (Cyprinus carpio), Songpu mirror carp, Weight-Length, Condition factor

\section{INTRODUCTION}

The common carp (Cyprinus carpio) is the oldest cultured and most domesticated fish in the world. They have been farmed for about 4,000 years in China and for several hundred years in Europe and they are one of the popular aquaculture species, comprising $13 \%$ of the total global freshwater aquaculture production in 2006 (FAO, 2007). Many strains of common carp developed through a combination of forces including adaptation, accumulation of mutations and natural as well as human breeding efforts
(Wohlfarth et al., 1983; Wohlfarth et al., 1984). Crossbreeding played a further role in the development various varieties, mainly through transplantation of domesticated European into other countries. A list of famous European varieties includes "Galician", "Aischgrunder", "Lausitzer" (Germany), "Bohemian” (Czechoslovakia), "Royale” (France), "Dinnyes" (Hungary), "Dor-70" (Israel) (Jhingran and Pullin, 1985). Israeli carp (Cyprinus carpio) is known as an important fish, such as sashimi and fishing in the inland aquaculture industry. By breeding in reservoirs elsewhere since its introduction in 1970 as part of the domestic food

\footnotetext{
Manuscript received October 15, 2016, Received in revised form November 12, 2016, Accepted December 5, 2016

${ }_{\dagger}^{\dagger}$ Corresponding Author : Jeong-Ho Lee, Natioanal Institute of Fisheries Science , NIFS, Changwon, 51688, Korea, Tel: +82-55-540-2780, Fax: +82-55546-6292, E-mail: jhlee7124@korea.kr

This is an Open Access article distributed under the terms of the Creative Commons Attribution Non-Commercial License (http:// creativecommons.org/licenses/by-nc/3.0) which permits unrestricted non-commercial use, distribution, and reproduction in any medium, provided the original work is properly cited.
} 
industry is keeping survived inland recent culture has been progress in the several farms. Growth and feed utilization studies of the 'Cyprinus carpio' have been reported (JO et al., 1998; Wang and Xu, 2006). Sonpu mirror carp (Cyprinus carpio) is a new kind of mirror carp based on $\mathrm{F}_{4}$ generation breeding lines of Germany mirror carp (Li et al., 2009). Because there were no research on breeding varieties introduced in China and Korea, so in this study we was conducted selection of broodstock on the Israeli carp such as length, weight and scales number and was conducted seed production.

The study of weight and length has applied value in fish biology. The significance of the studies in fishes is to assess the growth of fishes in different condition (Salam and Naeem, 1993). A fish can change its weight changing in length or vice versa. The relationship between weight and length for fish can be analyzed either by measuring weight and length of the same fish through their life or a sample of fish taken at a particular time (Wootton, 1990). It is in-vestigated in the carps of India (Jhingran, 1952; Chatterji et al., 1977) and also, the weight-length relationship provides an imformative opportunity to calculate an index commonly used by fisheries biologists to compare the condition factor, $\mathrm{K}\left(\mathrm{K}=100 \times \mathrm{W} / \mathrm{L}^{3}\right)$. Fish with a high value of $\mathrm{K}$ are heavy for its length, while fish with a low $\mathrm{K}$ value are lighter (Weatherly, 1972).

Therefore, the present study deals with the weightlength and condition factor of an important freshwater
Israeli carp (Cyprinus carpio). and determined the growth on different cross mating in Israeli carp as a preliminary study of breeding program (National Institute of Fisheries Science-R2016010) for Israeli carp.

\section{MATERIALS AND METHODS}

\section{Experimental fish}

The breeding for Israeli carp (Cyprinus carpio) was conducted at the Inland Aquaculture Research Center, National Institute of Fisheries Science, Changwon, Korea. The breeding experiments of cultivated Israeli carp (Cyprinus carpio) were purchased from a local fish farm from the Jeonbuk region and songpu mirror carp from Heilongjiang River Fisheries Research Institute, China. In the spring, sexually mature breeders were selected for production of families. A selection criterion of broodstock is the total length and the weight superior to the fist object. The following criteria were selected by a number of small scale objects. The average total length and weight of China and Korea population groups are as following Table 1.

\section{Artificial fertilization and seed production}

By crossing 2 Korea and 2 China, 4 groups were developed and investigated. Individually tagged brood fish were used for seed production of pair mating. Each group were kept separate, using four FRP square tank (dimension; $1.5 \mathrm{~m} \times 1.5 \mathrm{~m} \times 2 \mathrm{~m}$ ) the mating group was induced by the

Table 1. Broodstock of Jeonbuk (K) and Songpu mirror carp (C) (Cyprinus carpio)

\begin{tabular}{ccccccc}
\hline \hline & TL $(\mathrm{mm})$ & $\mathrm{BL}(\mathrm{mm})$ & $\mathrm{TW}(\mathrm{g})$ & $\mathrm{BH}(\mathrm{mm})$ & $\mathrm{BW}(\mathrm{mm})$ & $\mathrm{CF}$ \\
\hline K female & $488.1 \pm 29.26$ & $410.7 \pm 22.90$ & $2,875.4 \pm 466.82$ & $164.77 \pm 8.98$ & $88.75 \pm 9.470$ & $2.48 \pm 0.37$ \\
K male & $474.3 \pm 19.00$ & $401.4 \pm 13.55$ & $2,565.0 \pm 245.41$ & $165.49 \pm 9.95$ & $81.64 \pm 7.568$ & $2.41 \pm 0.34$ \\
C female & $496.9 \pm 27.91$ & $420.3 \pm 23.47$ & $2,698.6 \pm 83.02$ & $162.42 \pm 7.83$ & $88.41 \pm 6.350$ & $2.22 \pm 0.32$ \\
C male & $477.6 \pm 32.40$ & $405.5 \pm 25.94$ & $2,113.0 \pm 365.99$ & $147.45 \pm 10.02$ & $73.48 \pm 5.820$ & $1.93 \pm 0.20$ \\
\hline
\end{tabular}

TL : total length, BL : body length, TW : total weight, $\mathrm{BH}:$ body height, $\mathrm{BW}:$ body width, $\mathrm{CF}$ : condition factor. Values represent mean \pm S.D. 
temperature adjustment. At $23 \sim 25^{\circ} \mathrm{C}$ water temperature, hatching mainly took place after 48 50 h. Hatched larvae were reared at PP tank (dimension; $3 \mathrm{~m} \times 3 \mathrm{~m} \pi \times 0.7 \mathrm{~m}$ ) and during the culturing, each group was hand-fed four times daily at $3 \mathrm{~h}$ feeding intervals and the water temperature was maintained at $23 \sim 25^{\circ} \mathrm{C}$.

\section{Investigation of body length and body weight}

The survival and growth of each group were assessed at day 20, 40, 60 and 170 days post-hatch (DPH). A total of 500 fish were randomly sampled from the four groups, respectively, and used for growth measurements. Length and individual mean weight were measured using a ZEN lite 2012 software program. Condition factor was calculated from the relationship between the body weight (M) and the total length $(\mathrm{L})$ : Condition factor $=\left(\mathrm{M} / \mathrm{L}^{3}\right) \times 100,000$.

\section{Statistical analysis}

The data were analyzed by one-way ANOVA using the SPSS statistical package (SPSS 5.0; SPSS Inc., USA). Means were separated using Duncan's multiple range test and were considered different at $P<0.05$ (Duncan, 1995).

\section{RESULTS}

For the seed production, first we have selected a broodstock in order to the high length and weight and next, a scales small number of species were selected. Table 1 shows the growth measurements and condition factor of Israeli carp broodstock. The average total length and weight of Korean and Chinese population groups are as following: Korean female $(488.7 \pm 29.26 \mathrm{~mm}, 2,875.4 \pm 466.82 \mathrm{~g})$, Korean male $(474.3 \pm 19.00 \mathrm{~mm}, 2,565.4 \pm 245.41 \mathrm{~g})$ and Chinese female $(469.9 \pm 27.91 \mathrm{~mm}, 2,698.6 \pm 83.02 \mathrm{~g})$, and Chinese male (477.6 $\pm 32.4 \mathrm{~mm}, 2,113.0 \pm 365.99 \mathrm{~g})$ and condition factor were higher in the Korean broodstock group (female : $2.48 \pm 0.37$, male : $2.41 \pm 0.34$ ) then in the and Chinese broodstock group (female : $2.22 \pm 0.32$, male : $1.93 \pm$
0.20). 23 Domestic of 51 and 76 Chinese Israeli carp of 150 were selected and breeding. Mating methods for seed production was performed by dividing into four groups in the same manner as in Table 2. The hatching rate of mating group was no significant differences among the four groups (data not shown). Fig. 1 shows the growth frequency of Israeli carp. At day 20 days post-hatching (DPH), the total length of the $\mathrm{CC}$ group was slightly bigger than the other group and did not differ significantly among the four groups $(P>0.05)$. The comparative results for the total length for four groups are shown in Fig. 2. All experimenttal groups were not difference in the full length until 40

Table 2. Breeding combination for seed production

\begin{tabular}{|c|c|}
\hline Group & Parental combination \\
\hline $\mathrm{KK}$ & Jeonbuk Israel carp $(+) \times$ Jeonbuk Israel carp $(\overbrace{}^{\lambda})$ \\
\hline $\mathrm{KC}$ & Jeonbuk Israel carp $(+) \times$ Songpu mirror carp $(\overbrace{}^{\Uparrow})$ \\
\hline $\mathrm{CC}$ & Songpu mirror carp $(+) \times$ Songpu mirror carp $\left({ }^{\lambda}\right)$ \\
\hline CK & Songpu mirror carp $(+) \times$ Jeonbuk Israel carp $\left(\oslash^{\Uparrow}\right)$ \\
\hline
\end{tabular}

$\mathrm{K}$ : Jeonbuk, C : Songpu mirror carp.

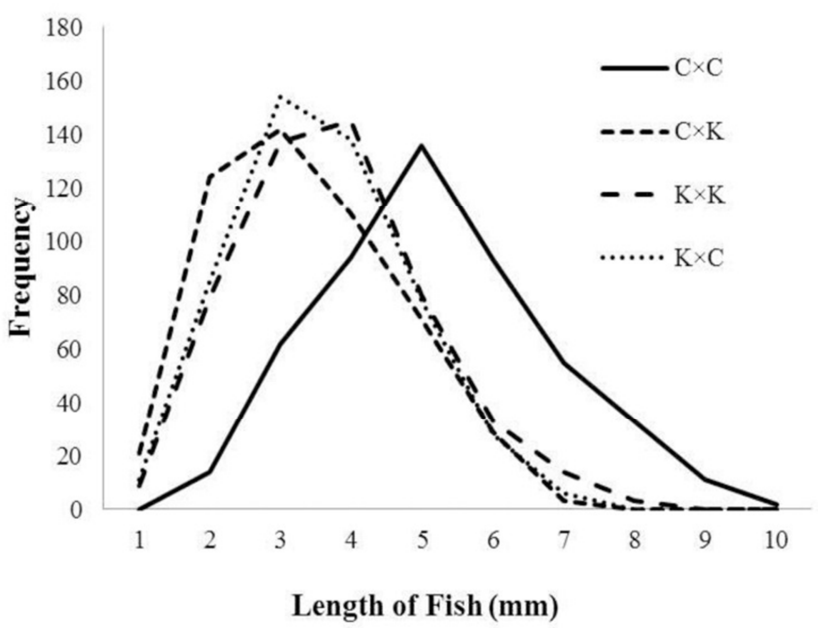

Fig. 1. Comparison of body size of larvae for Israel carp (Cyprinus carpio). The four groups were measured full length at 20 days post hatching (DPH), the CC group was higher compared with other groups. There was not sisnificantly difference $(P>0.05)$ in all groups. K ; Jeonbuk, C, Songpu mirror carp. 


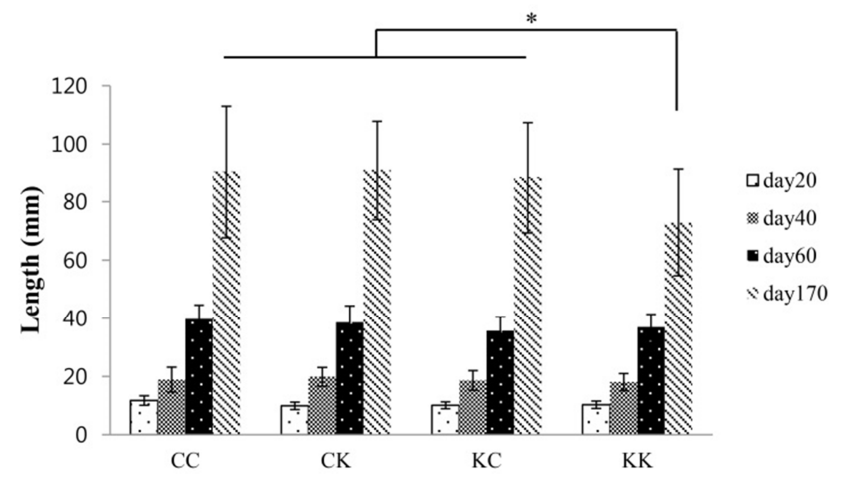

Fig. 2. Total length of the $\mathrm{CC}, \mathrm{CK}, \mathrm{KC}$, and $\mathrm{KK}$ group.

Total length of the Israeli carp (Cyprinus carpio) was determined at 20, 40, 60 and 170 days post hatching (DPH). The CK group was higher compared with other groups. There was significantly differrence $\left({ }^{*} P<0.05\right)$ in all groups. $\mathrm{K}:$ Jeonbuk, $\mathrm{C}:$ Songpu mirror carp.

DPH. On day 170 after culturing, the sizes of the $\mathrm{CC}$ and CK group were measured at $90.32 \pm 22.64 \mathrm{~mm}$ and $90.80 \pm$ $16.9 \mathrm{~mm}$. On the other hand, a size of $\mathrm{KK}$ and $\mathrm{KC}$ group were measured at $72.85 \pm 18.17 \mathrm{~mm}$ and $88.31 \pm 19.00 \mathrm{~mm}$. The measured sizes of each group at $170 \mathrm{DPH}$ were larger in the $\mathrm{CC}$ and $\mathrm{CK}$ group than in the $\mathrm{KK}$ and $\mathrm{KC}$ group. In the length of the CC group were greater compared with the KK group (1.23-fold). Survival rate of the all group was $100 \%$ and there was not difference. Condition factor $(\mathrm{K})$ provides index of weight-length relationship (Weatherly, 1972). The analysis of condition factor in the four groups is Table 3. The value of $\mathrm{K}$ was greater in the $\mathrm{CC}$ group (2.93) compared in the $\mathrm{KK}$ and $\mathrm{KC}$ group (2.43 and 2.38).
The length-weight relationship of four groups is representted in Fig. 3, at $60 \mathrm{DPH}$, although KK group was found to be smaller than $\mathrm{CK}$, the length-weight curves of the all group increased at a point $40 \mathrm{~mm}$ and $60 \mathrm{~mm}$. This suggest that growth and condition factor were high in the $\mathrm{CC}$ and CK group when using the Chinese broodstock combination. The growth of Israeli carp significantly related on the female broodstock

\section{DISCUSSIONS}

Israeli carp (Cyprinus carpio) is a commercially important farmed species in South Korea and the north of China, which has favorable growing characteristics and resistance to diseases. German mirror carp (Cyprinus carpio) is popular freshwater fish reared in Europe because of fastgrowing rate, feed efficiency, cold resistance and easy domestication. It was introduced to China in 1984, but could not adapt well to different aquaculture condition. So, the breeding study for better variety was done by Heilongjiang River Fishery Institute. After several years, a selected strain called 'songpu mirror carp' was successfully cultivated. It has the good characteristics of German mirror carp such as few scale and high growth and survival rate and resistance for disease have been improved (Li et al., 2009).

In this study, we was conducted breeding work between the domestic and songpu mirror carp induced from China and seed was produced from the four group mating. Cro-

Table 3. Growth, condition factor and survival of Israel carp (Cyprinus carpio) at 170 days post hatching (DPH)

\begin{tabular}{ccccc}
\hline \hline Group & Survival (\%) & Final length $(\mathrm{mm})$ & Final weight $(\mathrm{g})$ & Condition factor \\
\hline KK & $100.0 \pm 0.00$ & $72.85 \pm 18.17^{\mathrm{a}}$ & $11.21 \pm 5.82^{\mathrm{a}}$ & $2.43 \pm 0.82^{\mathrm{a}}$ \\
KC & $100.0 \pm 0.00$ & $88.31 \pm 19.00^{\mathrm{b}}$ & $14.92 \pm 9.85^{\mathrm{b}}$ & $2.38 \pm 1.55^{\mathrm{a}}$ \\
CC & $100.0 \pm 0.00$ & $90.32 \pm 22.64^{\mathrm{b}}$ & $18.04 \pm 11.93^{\mathrm{c}}$ & $2.93 \pm 2.88^{\mathrm{b}}$ \\
CK & $100.0 \pm 0.00$ & $90.80 \pm 16.90^{\mathrm{b}}$ & $15.28 \pm 11.03^{\mathrm{b}}$ & $2.13 \pm 1.49^{\mathrm{a}}$ \\
\hline
\end{tabular}

Values represent mean \pm standard deviation; means in the same column with diffenrent letters are significantly different $(P<0.05)$ as determined by Duncan's. K : Jeonbuk, C : Songpu mirror carp. Condition factor $=\left(\mathrm{M} / \mathrm{L}^{3}\right) \times 100,000$ where $\mathrm{M}$ is the body weight $(\mathrm{g}), \mathrm{L}$ is the total length $(\mathrm{mm})$. 

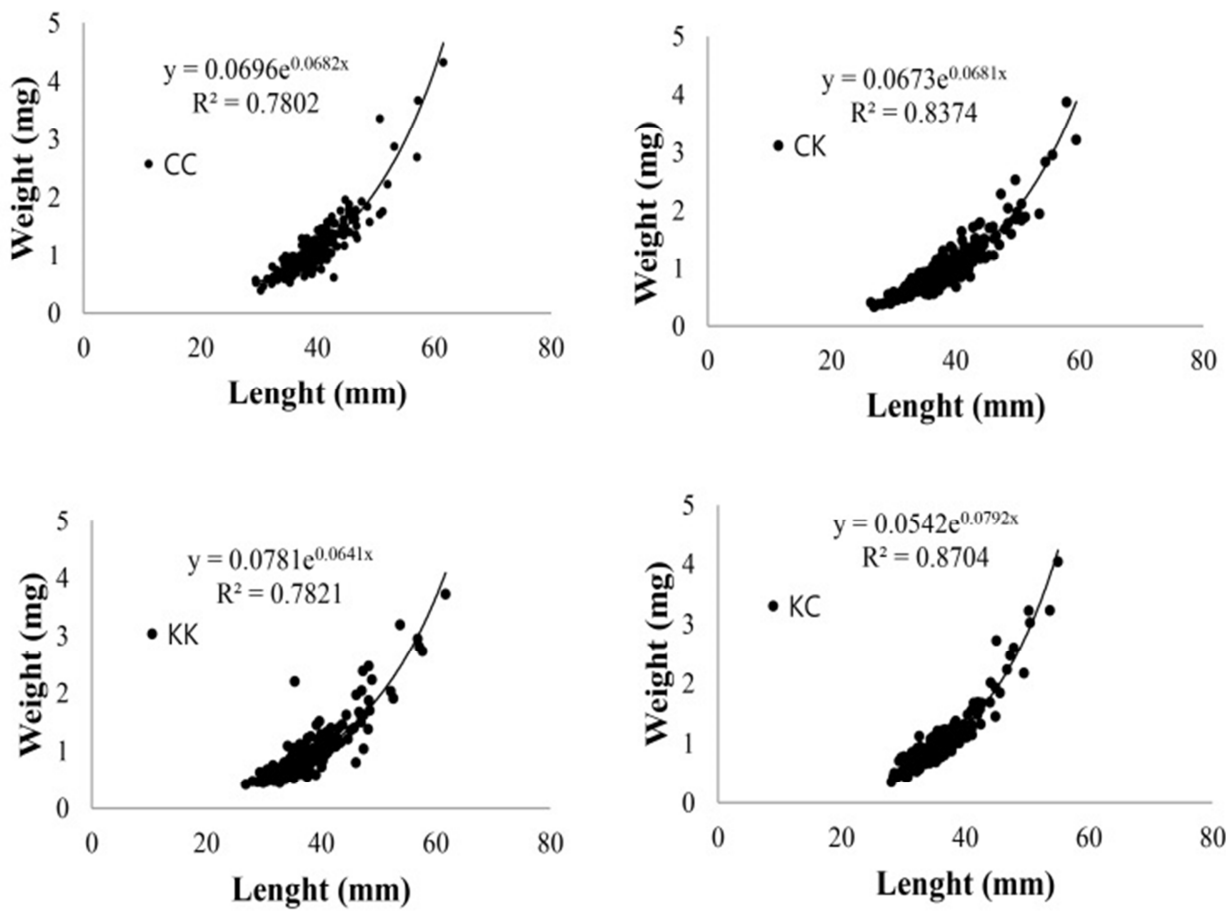

Fig. 3. Relationship between length ( $\mathrm{mm}$ ) and body weight (g) in Cyprinus carpio. Length and weight of Juve-nile were measured at 60 days post hatching (DPH). Smooth curve represents the calculated weight. K : Jeonbuk, C : Songpu mirror carp.

ssing experiments showed that different combinations of parents showed positive heteosis, manifested in growth rate, survival and feed conversion (Bakos, 1995). Length and weight of each group were measured at days, 20, 40, 60 and 170. The weight-length relationship provides an index commonly used by growth rate. Several studies on weight-length have been carried out in other fish species (Naeem MA and Khan, 1992; Naeem MA and Bhatt, 2000; Naeem MA and Salam, 2004). At day 60 and 170 culturing, length and weight of the $\mathrm{CC}, \mathrm{CK}$ and $\mathrm{KC}$ group were significantly bigger than in KK group $(P<0.05)$ also condition factor was high in the CC and CK group. Similar research has been reported recently for common carp (Dong et al., 2015) as well as other aquatic animal species such as tilapia (Hamzah A et al., 2014).

Water temperature was maintained at $23 \sim 25^{\circ} \mathrm{C}$ for the best culture condition. In 1988, Blaxter reported that temperature had an intense effect on fish growth also similar results were obtained from the study at effect on temperature on growth of Songpu mirror carp (Wang et al., 2014). Wang and his colleagues reported that fishes had higher weight gain rate at $22^{\circ} \mathrm{C}$ and $26^{\circ} \mathrm{C}$. This indicated that growth improvement of Songpu mirror carp was affected by temperature. So, in the present study, four groups of $C$. carpio were kept at $23 \sim 25^{\circ} \mathrm{C}$.

Our results of length and weight measurement were higher in the Chinease brooder group than in Korean brooder group. Generally, the growth rates of fish are involved are many internal and external factors and among them, the greater the impact on the female broodstock (Heath et al., 1999). In tilapia, female ratios are important factor for highest seed production (Khater, 2002). Condition factor are used for index of growth in fish (Weatherly, 1972). The value of condition factor was greater in the $\mathrm{CC}$ group compared in the $\mathrm{KK}$ and $\mathrm{KC}$ group and there are significantly difference both groups. The condition factor will 
increase with increase in length in C. carpio. Although significant differences were observed in growth and condition factor at each group. This is needed more researches to confirm as the fish grows.

The few improvement projects, especially in China from 2004 to 2014 (Dong et al., 2015) have been successfully applied to the genetic improvement and selective breeding for increased harvest body weight resulted in significant improvement in growth performance. Our results, when considered with those reported by Dong et al. suggest that growth was improved from the selection and genetic diversity.

In conclusion, length and weight of $C$. carpio have a faster growth in $\mathrm{CC}$ and $\mathrm{CK}$ combination groups and maybe mainly depended on female breeder when songpu mirror carp was broodstock. But survival significantly was not affected in the sex of broodstock and Because of that all groups had $100 \%$ survival rate. Further to the successful otcome from the cross mating for $C$. carpio in the population of four groups, we will analyze the feed efficiency, scale number and disease resistance on the four groups.

\section{ACKNOWLEDGEMENT}

This work was supported by a grant from the National Institute of Fisheries Science (R2016010).

\section{REFERENCES}

Bakos J (1995) Genetic improvement of common carp strains using intraspecific hybridization. Aquaculture 129:183-186.

Chatterji A, Siddiqui AQ, Khan AA (1977) Length-weight relationship of a carp, Labeo bata (Ham). Indian Acad Sci 86:189-194.

Dong Z, Nguyen H, Zhu W (2015) Genetic evaluation of a selective breeding program for common carp Cyprinus carpio conducted from 2004 to 2014. BMC Genetics 16:1-9.

Duncan DB (1995) Multiple range and multiple F tests. Biometrics 11:1-42.

FAO Fisheries Department (2007) Fisheries Statistics. FAO-Rome. http://www.fao. org/ figis/servlet.

Hamzah A, Ponzoni RW, Nguyen NH, Khaw HL, Yee HY, Nor SAM (2014) Genetic evaluation of the Genetically Improved Farmed Tilapia (GIFT) strain over ten generations of selection in Malaysia. Pertanika J Trop Agric Sci 37(4):411-29.

Heath DD, Fox CW, Heath JW (1999) Maternal effects on offspring size: Variation through early development of Chinook salmon. Evolution 53:1605-1611.

Jo JY, Hue CH, Park JH, Yoon GH, Kim YH, Oh SY, Bai SC (1998) Effects of fish meal analogue on the growth of Israeli strain of Common carp, Cyprinus carpio. J Aquacult 11: 487-493.

Jhingran VG (1952) General length-width relationship of three major carps of India. Proc Nat Inst Sci 18:449-460.

Jhingran VG, Pullin RSV (1985) A hatchery manual for the common, Chinese and Indian major carps. ICLARM Stud Rev 11:191.

Khater AM (2002) Effect of sex ratio on reproductive performance of Nile tilapia (Oreochromis niloticus) and blue tilapia (Oreochromis aureus). Egypt J Agric Res 80:377-386.

Li CZ, Y JZ, Hu X, Shi L (2009) Comparative studies on measurable characters and the number of scales in Sonpu mirror carp and German mirror carp selection strain. Chi J Fish 22:53-61.

Naeem MA, Khan MN (1992) Morphometric studies of an exotic fish Orechromis nilotica in relation to body size. Proc Pak Cong Zool 12:599-605.

Naeem MA, Bhatti MN (2000) Morphometric studies of cold water fish rainbow trout and Oncorhynchus mykiss in relation to body size. Pak J Zool 1: 55-62. 
Naeem M, Salam A (2004) Morphometric studies of Orechromis nilotica (male) in relation to body size from Islamabad. Pak J Zool 19:73-81.

Salam AM, Naeem ZB (1993) Length-weight and condition factor relationship of fresh water Chinese carp, from fish hatchery Islamabad. Pak J Res 5:45-48.

Wohlfarth GW, Moav R, Hulata G (1983) A genotypeenvironment interation for growth rate in the commn carp, growing in intensively manured ponds. Aquaculture 33:187-195.

Wohlfarth GW, Feneis B, Von LM, Hulata G (1984) Application of selective breeding of the common carp to European aquaculture. Eur Maricult Soc 8:177-193.
Wang Y, Xu Z (2006) Effect probiotic for common carp (Cyprinus carpio) based on growth performance and digestive enzyme activities. Animal Feed Sci \& Tch 127:283-292.

Wootton RJ (1990) Ecology of Teleost Fishes. Chapman and Hall, London.

Weatherly AH (1972) Growth and Ecology of Fish Population. Academic Press, London.

Wang CA, Xu QY, Zhao ZG, Li JN, Wang LS, Luo L (2014) Effects of dietary protein and temperature on growth and flesh quality of Songpu Mirror carp. Jounal of North 21:53-61. 